Dept. of Biomedical Science, College of Veterinary Medicine,

Sudan University of Science and Technology, Sudan.

E.mail; shamshahmed@sustech.edu or shamshahmed@yahoo.com

\title{
EFFECT OF FEEDING DIFFERENT LEVELS OF BALANITE AEGYPTIACA KERNEL CAKES ON SOME HEMATOLOGICAL AND SERUM BIOCHEMICAL PARAMETERS IN INDIGENOUS KENANA STEERS IN THE SUDAN \\ (With 4 Tables)
}

\section{By}

\section{SH. H. AHMED; M.G. MORKAZ* and SHADIA A. OMER \\ * Department of Animal Physiology, Faculty of Animal Production, University of Geizra, Sudan. \\ (Received at 13/9/2011)}

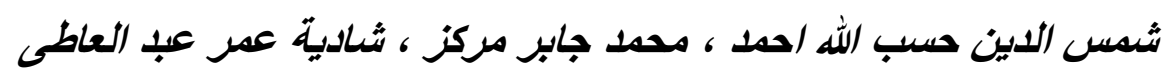

\section{SUMMARY}

This experiment was conducted to investigate the effect of feeding different levels of Balanite aegyptiaca seed cake on some blood parameters in Kenana steers. Four rations were formulated and Balanite aegyptiaca was incorporated into steers' rations at three levels, zero, 5, 10 and $20 \%$ to replace similar proportions of groundnut cake. Blood samples were collected from the jugular vein and analyzed for red blood cells count (RBCs), hemoglobin concentration $(\mathrm{Hb})$, packed cell volume (PCV), erythrocyte sedimentation rate (ESR) and white blood cells count (WBCs), as well as analyses of serum parameters (glucose, cholesterol, urea, total protein and albumin). All data were analyzed using descriptive statistics and analysis of variance. The results showed that the mean values of RBCs, Hb concentration, PCV, ESR and WBCs did not differ significantly $(\mathrm{P}>0.05)$ among the different animal groups, nor a significant effect $(\mathrm{P}>0.05)$ on serum glucose, cholesterol, total protein or albumin. Significant variation, however, $\left(\mathrm{P}<_{0} .05\right)$ was observed in blood urea levels between animals fed $0 \%$ and those fed $20 \%$ kernel seed cakes (31.33 vs. $28.67 \mathrm{mg} / \mathrm{dl})$. It is be concluded that B. aegyptiaca 
seed cake has a nutritional value and can replace up to $20 \%$ groundnut cake without adverse effects on some hematological and serum biochemical parameters of steers.

Key words: Balanite aegyptiaca, seed cake, blood hematology, blood chemistry.

\section{INTRODUCTION}

Balanite aegyptiaca mature tree produces as many as 10,000 yellow, date-like fruits annually. Each fruit weighs 5-8 $\mathrm{g}$ and, consists of an epicarp (5-9\%), a mesocarp or pulp (28-33\%), an endocarp (49$54 \%)$ and a kernel (8-12\%). The oil content of desert date kernel approaches 50\% (Chapagain and Wiesman, 2005). Balanites aegyptiaca kernel cake (BKC) is produced from the fruit of Balanites aegyptiaca after oil extraction, the cake is characterized by high protein $(36.8 \%)$ and low crude fibre (5.9\%) contents, (ElKhiedir et al., 1983). The kernel meal, the residue remaining after oil extraction was used for fattening sheep in the Sudan (Elkhideir, et al., 1983) and in other animals in Senegal, (Vogt, 1995) and as stock feed in Uganda. (Katende et al., 1995).

$\mathrm{BKC}$ is non toxic to ruminants and its addition at the rate of $20 \%$, together with $10 \%$ straw, can replace $30 \%$ Cotton seed cake in the diet (Elkhideir et al., 1983). The B. aegyptiaca diet was also found to be substantially cheaper. The objective of this work therefore is to incorporate this unconventional locally available cheap feed stuff in ruminantis feed and to investigate the effect of feeding different levels of BKC on some blood parameters in Kenana steers.

\section{MATERIALS and METHODS}

Experimental Diets: Four experimental diets of different ingredients were used. (Table 1). Diets were almost isocaloric and isonitrogenous. The BKC was obtained after mechanical extraction of the oil from the decorticated seeds. 
Table 1: Composition of experimental rations.

\begin{tabular}{|c|c|c|c|c|}
\hline Diets & $\mathrm{A}$ & $\mathrm{B}$ & $\mathrm{C}$ & $\mathrm{D}$ \\
\hline Bngredients\% & & & & 20 \\
\hline GKC & zero & 5 & 10 & Zero \\
\hline Dura & 30 & 30 & 30 & 30 \\
\hline Wheat bran & 19 & 19 & 19 & 19 \\
\hline Molasses & 30 & 30 & 30 & 30 \\
\hline Salt (NaCl) & 1 & 1 & 1 & 1 \\
\hline Total & 100 & 100 & 100 & 100 \\
\hline
\end{tabular}

$\mathrm{BKC}=$ Balanite aegyptiaca seed cake $\mathrm{A}=$ Diet with zero $\mathrm{BKC}$

$\mathrm{B}=$ Diet with $5 \% \mathrm{BKC}$

$\mathrm{C}=$ Diet with $10 \% \mathrm{BKC}$

$\mathrm{D}=$ Diet with $20 \% \mathrm{BKC}$

The Chemical composition of the various diets is shown in Table 2

Table 2: Proximate analysis of the experimental diets.

\begin{tabular}{|c|c|c|c|c|c|c|c|}
\hline $\begin{array}{c}\text { \%ariable } \\
\text { \%Rations }\end{array}$ & DM & EE & CP & CF & Ash & NFE & $\begin{array}{c}\text { ME } \\
\text { Kcal/g }\end{array}$ \\
\hline A & 87.3 & 3.1 & 18.2 & 5.5 & 7.05 & 43.15 & 11.89 \\
\hline B & 86.9 & 2.9 & 18.3 & 5.4 & 6.34 & 43.16 & 11.81 \\
\hline C & 86.6 & 2.3 & 18.1 & 5.3 & 6.82 & 44.08 & 11.51 \\
\hline D & 86.3 & 2.1 & 18.4 & 5.2 & 6.15 & 44.25 & 11.43 \\
\hline
\end{tabular}

DM= Dry matter: CP: Crude protein: EE: Ether Extract: NFE: Nitrogen free extract: MEKcal/g: Metabolisable energy 


\section{Experimental animals:}

Four castrated Local breed (Kenana) steers, aged 2 - 21/2 years, were fitted with rumen cannulae as described by Brown et al. (1968). The animals were divided randomly to one of the experimental diets. The experimental designed was $4 \times 4$ Latin square, with four treatments and four experimental periods, each of 10 days. The steers were allowed a 14 days adaptation period to the experimental diets followed by 7 days of sampling.

\section{Blood sample collection and analysis:}

Blood samples were collected weekly through the jugular vein during the experimental period (40 days) into two well labeled sets of sample bottles. One set contained anti-coagulant and this was used immediately for the hematological study. The other set contained no anti-coagulant was kept in the refrigerator at about $4{ }^{\circ} \mathrm{C}$ for about 3 hours for sedimentation. Sera were then harvested by centrifugation centrifuge at 3,000 rpm for 10 minutes and were stored at $-20^{\circ} \mathrm{C}$ pending analysis.

\section{Chemical analysis:}

The BKC and experimental diets were taken and analyzed according to A.O.A.C (1995) for their proximate composition.

The concentration of haemoglobin $(\mathrm{g} / 100 \mathrm{ml}$ of blood) was measured by the yanmethaemolobin technique using a haemoglobin meter. The PCV percentage was read off on the scaling instrument provided with the centrifuge. Red blood cells were counted with an improved Neubauer haemocytometer (Hawksley and Sons Ltd., England). Formal citrate was used as a diluent. White blood cells were counted with an improved Neubauer haemocytometer (Hawksley and Sons Ltd., England). Turk's fluid (1\%glacial acetic acid tinged with gentian violet) was used as a diluent. The number of WBCs is expressed $10 / \mathrm{ml}$.

Serum concentration of total protein (TP), albumin (Alb), glucose, cholesterol, and Urea, were determined by colorimetric method, using commercial kits (Linear Chemicals Ltd. - Spain), following the procedures set by the manufacturer. $\mathrm{Na}$ and $\mathrm{K}$ were measured by a flame photometer (Corning 400, England).

\section{Statistical analysis:}

The experiment was a randomized complete block design. All the experimental data were subjected to analysis of variance using SAS (1998) and where statistical significance was observed, the mean values were separated using the Duncan Multiple Range Test (Duncan, 1980). 


\section{RESULTS}

\section{Haematological characteristics of steers fed experimental diets:}

The results of the blood indices are presented in Table 3. No significant differences $(\mathrm{p}>0.05)$ were recorded for all parameters investigated as shown in Table 3 when the steers were fed BKC.

\section{Serum Metabolites of steers fed experimental diets:}

The results of the serum biochemistry of the steers fed different level of B. aegyptiaca kernel cakes are presented in Table 4. No significant differences $(p>0.05)$ were recorded for all the parameters measured except urea concentration which was significantly lower in animal fed $20 \%$ than the other groups $(\mathrm{p}<0.05)$ between the treatment means. The blood urea concentration for diet containing $20 \%$ kernel cake was significantly lower $(\mathrm{p}>0.05)$ when compared with the other diets.

Table 3: Haemagram parameters of the steers fed different level of $B$ aegyptiaca cakes (Mean $\pm \mathrm{SD}$ ).

\begin{tabular}{|l|ccccc|}
\hline \multirow{2}{*}{ Diets } & \multicolumn{5}{|c|}{ Balanites aegyptiaca kernel cake \% in experimental diets } \\
\cline { 2 - 6 } Parameters & 0 & 5 & 10 & 20 & Sig.level \\
\hline R.B.Cs $\times 10^{6} / \mathrm{ml}$ & $10.15 \pm 0.01$ & $10.12 \pm 0.01$ & $10.28 \pm 0.01$ & $10.38 \pm 0.01$ & $\mathrm{NS}$ \\
Haemoglobin $\mathrm{g} / \mathrm{dl}$ & $17.66 \pm 0.93$ & $17.68 \pm 1.23$ & $18.23 \pm 0.59$ & $18.46 \pm 0.80$ & $\mathrm{NS}$ \\
P.C.V. $(\%)$ & $29.66 \pm 2.90$ & $28.66 \pm 3.71$ & $30.00 \pm 1.52$ & $30.33 \pm 2.60$ & $\mathrm{NS}$ \\
E.S.R. $\mathrm{mm} / \mathrm{hour}$ & 1.00 & 1.00 & 1.00 & 1.00 & $\mathrm{NS}$ \\
W.B.Cs $\mathrm{x} 10^{3} / \mathrm{ml}$ & $9.16 \pm 0.6$ & $9.11 \pm 0.6$ & $9.08 \pm 0.5$ & $9.13 \pm 0.5$ & $\mathrm{NS}$ \\
& & & & & \\
\hline
\end{tabular}

Sig: $\quad$ significant at $(\mathrm{p}<0.05)$ : Zero: Diet with zero BKC (control group)

R. B. Cs: Red blood cells. : P.C.V: Packed cell volume. E. S. R: Erythrocyte sedimentation rate.

W. B. Cs: White blood cell count. NS: Not significant. SD: Standard Deviation 
Table 4: Some serum constituents of the steers fed different level of B. aegyptiaca kernel cakes (Mean $\pm \mathrm{SD})$.

\begin{tabular}{|l|ccccc|}
\hline \multirow{2}{*}{ Treatments } & \multicolumn{5}{|c|}{ Balanites aegyptiaca kernel cake \% } \\
\cline { 2 - 6 } Parameters & 0 & 5 & 10 & 20 & Sig.level \\
\hline Glucose mg/dl & $71.33 \pm 8.45^{\mathrm{a}}$ & $69.00 \pm 3.46^{\mathrm{a}}$ & $68.00 \pm 15.3^{\mathrm{a}}$ & $66.33 \pm 2.60^{\mathrm{a}}$ & $\mathrm{NS}$ \\
Cholesterol mg/dl & $131.67 \pm 1.33^{\mathrm{a}}$ & $132.23 \pm 1.45^{\mathrm{a}}$ & $132.33 \pm 1.76^{\mathrm{a}}$ & $133.53 \pm 3.17^{\mathrm{a}}$ & $\mathrm{NS}$ \\
Total protein g/dl & $7.90 \pm 0.06^{\mathrm{a}}$ & $7.87 \pm 0.09^{\mathrm{a}}$ & $7.80 \pm 0.06^{\mathrm{a}}$ & $7.80 \pm 0.03^{\mathrm{a}}$ & $\mathrm{NS}$ \\
Albumin g/dl & $3.90 \pm 0.06^{\mathrm{a}}$ & $3.83 \pm 0.09^{\mathrm{a}}$ & $3.80 \pm 0.06^{\mathrm{a}}$ & $3.77 \pm 0.09^{\mathrm{a}}$ & $\mathrm{NS}$ \\
Urea mg/dl & $31.33 \pm 0.88^{\mathrm{a}}$ & $30.33 \pm 0.88^{\mathrm{a}}$ & $30.33 \pm 0.88^{\mathrm{a}}$ & $28.67 \pm 0.87^{\mathrm{b}}$ & $\mathrm{S}$ \\
& & & & & \\
\hline
\end{tabular}

Sig: $\quad$ significant at $(\mathrm{p}<0.05)$. Zero: Diet with zero BKC (control group)

NS : Not significant. SD : Standard Deviation

\section{DISCUSSION}

In this study, blood RBCs, WBCs, $\mathrm{Hb}$ and PCV \% were in general similar to those reported by Elbashier et al. (2006), and lower than those of previous researchers Wahbi et al. (1976) and Hind (2007) for cross bred cows. However, the generally lower blood RBCs, WBCs, $\mathrm{Hb}$ and PCV \% in the current study may be due to differences in dietary intake However, pervious studies have shown that, the composition of blood in animals is affected by various factors, such as seasonal change in environment elements, nutritional status, water balance, physiological state and age of animals (Anderson, 1980)

Blood glucose in this study did not differ significantly between the different levels of $B$. aegyptiaca kernel cake, which is in agreement with the results reported by Steen (1988); Sil (1992); Hamed et al. (2001); Tiwari (2001). However, Pattanaik et al. (1999) showed that, Blood glucose did not differ significantly with the protein sources. In this study, the observed range of glucose $(66.33-71.33 \mathrm{mg})$ was higher than that reported by Sil (1992) in cross bred cattle calves fed on four different protein sources (51.9-64.1 $\mathrm{mg} \%)$. 
Total protein values observed in the present study $(7.5 \mathrm{~g})$ is compared with value reported by Sil (1992) in crossbred cattle calves fed on three different protein sources $(7.75 \mathrm{~g} \%)$, and close to the normal range of 6.75-7.82 g/100 $\mathrm{ml}$ reported by Gupta et al. (1988). There was no significant effect of dietary protein source on either serum cholesterol or albumin concentrations, which is in agreement with finding of Hamed et al. (2001). However Park et al. (1980), found that concentrations of free cholesterol was higher $(\mathrm{P}<0.05)$ for heifers on low protein rations $(28.2 \mathrm{mg} / 100 \mathrm{ml})$ as compared to those fed high protein diets $(17.9 \mathrm{mg} / 100 \mathrm{ml})$.

Serum urea in this study was significantly affected by an increase in dietary protein source. However, concentration of serum urea was significantly affected by dietary protein (Tiwari 2001). Increased ammonia concentrations in the blood may be caused by an oversupply of kernel seed cake in the rumen (Kenny et al., 2001). The results obtained in this experiment are within the normal physiological values of 28.67 $31.33 \mathrm{mg} \%$ which were within the range reported by Patel and Anaokar, (1971) for buffalo calves $(10.30 \mathrm{mg} / 100 \mathrm{ml})$ and within the range reported by Sil (1992) (16.9-17.8 $\mathrm{mg} \%)$ on three different protein sources. Pattanaik et al. (1999) did observe any significant effect on blood urea in calves fed different protein sources. However, many researchers reported changes in some of the important blood constituents on feeding different levels of dietary protein (Sarma, 1973; Gangadevi and Kunjikutty, 1984). The lack of significance between the biochemical parameters particularly the total protein suggests that the protein quality was adequate at all levels of $B$. aegyptiaca kernel cake inclusion considered. It is concluded that BKC did not affect neither hematological nor serum parameters.

\section{ACKNOWLEDGEMENT}

This work was kindly financed by the Scientific Research CouncilSudan University of Science and Technology. 


\section{REFERENCES}

Anderson, N.V. (1980): Veterinary Gastroenterology Lea and Febiger, Philadelphia. Anim. Res. 50: 205-211.

AOAC (1990): Official Method of Analysis. Association of Official Analytical Chemists. $15^{\text {th }}$ edition. Washington, DC. USA. pp. 66-88.

Brown, G.F.; Armestrong, D.G. and Macrae, J.C. (1968): The establishment in one operation of a cannula into the rumen and re-entrant cannulae into the duodenum and ileum of the sheep. $\mathrm{Br}$ Vet. J.; 124(2): 78-82.

Chapagain, B.P. and Wiesman, Z. (2005): Variation in diosgenin level in kernel among different provenances of B. aegyptiaca Del. (Zygophyllaceae) and its correlation with oil content, Afr. J. Biotechnol. 4: 1209-1213.

Duncan, D.B. (1955): Multiple ranges and multiple F -tests. Biometrics, 11: $1-42$.

Elbasheir, M.O.; Shadia, A. and Khadiga, A. (2006): Effect of feeding partial increasing levels of Cajanus cajan on some Blood Components of Nubian Goat Kids. Sud. Vet. Sci. and Anim Husb. 45: 54-67.

Elkhiedeir, O.A.; Gumaa, A.Y.; Fangali, O.A.I. and Badir, N.A. (1983): The use of Balanites kernel cake in a diet for fattening sheep., Anim. Feed Sci. and Tech. 9: 301-306.

Garry, A.B. (2005): The Effect of Different Rations of Groundnut Hulls and Molasis on Feedlot Performance and Carcass Characteristics of Cross Breed Goats. M. Sc. Sudan University of Scienceand Technology

Gupta, B.N.; Krishna, J.; Chopra, R.C. and Arora, S.P. (1988): Nutrient utilization from wheat straw or supplemented with green fodder in crossbred cattle. Ind. J. Anim. Nutr. 5: 100-104.

Hind, A.A. (2007): Effect of physiological status and season of calving on milk yield, milk composition and blood constituents. M.Sc. Thesis, Sudan University of science and technology - Sudan.

Katende, A.; Birne, Ann and Tengnas, Bo (1995): Useful trees and shrubs for Uganda. Identification, propagation and management for agriculture and pastoral communities. Kampala and Nairobi. Regional Soil Conservation Unit. RSCU/SIDA Technical Handbook Series 10. 
Kenny, D.A.; Boland, M.P.; Diskin, M.G. and Sreenan, J.M. (2001): The effect of crude protein and fermentable carbohydrate intake on blood metabolite concentrations and fertility in beef heifers. Pages 323-329 in Fertility in the High-Producing Dairy Cow, Occasional Publications No. 26, Br. Soc. Anim. Sci., Edinburgh, UK

Pattanaik, A.K.; Sastry, V.R.B. and Katiyar, R.C. (1999): Effect of different degradable protein and starch sources on the blood and rumen biochemical profile of early weaned crossbred calves. Asian-Aust. J. Anim. Sci. 12: 728-734.

SAS (1998): Statistical Analysis Systems user's guide (Version 6.14), SAS Institute, Inc., Cary, N.C., USA.

Sil, B. (1992): Comparative studies on feeding of different conventional proteins in urea containing diet on performance of crossbred calves. M.Sc. Thesis, Deemed University, IVRI, Izatnagar, India.

Singh, P. (1991): Utilization of nutrients from straw as affected by mode of NPN supplementation. Ph.D. Thesis, Deemed University, IVRI, Izatnagar, India.source of dietary protein on intake and milk yield in dairy cows.

Steen, R.W.J. (1988): The effect of supplementation of silage-based diets with soybean and fish meal for finishing beef cattle. Anim. Prod. 46: 43.

Tiwari, C.M, Chandramoni1, A.S.; Jadhao2, S.B.; Gowda3, S.K. and Khan, M.Y. (2001): Studies on blood biochemical constituents and rumen fermentation in growing buffalo calves fed ammoniated straw-based rations supplemented with different protein sources Izatnagar, 243 122, India

Vogt, K. (1995): A field guide to the identification propagation and uses of common trees and shrubs of dry land Sudan. SOS Sahel International (UK).

Wahbi, A.A.; IDris, O.F. and Yassin, T.T. (1976): A physio- chemical Study on the blood of desert sheep in the Sudan. Part 1. Proc. of both Vet. Conference. 